\title{
Therapeutic trial on clinical cases of impactive and spasmodic colic in donkeys in Gondar, northwest Ethiopia
}

\author{
G.F. Kassa ${ }^{1}{ }^{\oplus}$, K. Amenu² and B. Ayele ${ }^{3}$ \\ ${ }^{1}$ School of Veterinary Medicine, Wolaita Sodo University, ${ }^{2}$ Livestock and fishery office, Simada woreda, Amhara regional \\ state, ${ }^{3}$ College of Veterinary Medicine and Animal Science, University of Gondar, Gondar, Ethiopia
}

\begin{tabular}{l} 
Article information \\
\hline Article history: \\
Received June 20, 2020 \\
Accepted April 27, 2021 \\
Available online October 1, 2021 \\
\hline Keywords: \\
Colic \\
Donkey \\
Ethiopia \\
Gondar \\
Therapeutic trial \\
\hline
\end{tabular}

\section{Correspondence:}

G.F. Kassa

fantaye12@gmail.com

\begin{abstract}
The therapeutic trial was conducted from December 2018 to May 2019 to compare the therapeutic efficacy of different drug regimens in the treatment of impactive and spasmodic colic in donkeys in Gondar, Northwest Ethiopia. Twenty-five purposively selected donkeys were used in this study. Ten of them were showing suspected clinical signs of impactive colic and the remaining ten were with spasmodic colic. The rest five donkeys were kept as control group. For this trial, each disease category was again grouped into two subgroups. The first sub-group in group A with suspected spasmodic colic was treated with ivermectin and, the second sub-group was treated with fenbendazole. Similarly, the first subgroup in group B with suspected impactive colic was treated with meloxicam and the remaining subgroup was treated with hyoscine butyl bromide. Most vital parameters were recorded before and after treatment of colicky donkeys. Feces and blood samples were collected and examined pre and post treatment from each donkey. Donkeys treated with ivermectin subcutaneously have $97.3 \%$ fecal egg count reduction percentage, whereas donkeys treated with fenbendazole orally have fecal egg count reduction percentage of $79.85 \%$. Donkeys treated with meloxicam, most of the clinical signs disappear within 24 hours of time after treatment. Subcutaneous administration of ivermectin was effective for the treatment of spasmodic colic due to Strongyle infestation in donkeys. Therefore, field veterinarians should practice subcutaneous administration of ivermectin and intramuscular administration of meloxicam for effective treatment of spasmodic and impactive colic in donkeys, respectively.
\end{abstract}

DOI: $10.33899 /$ ijvs.2021.127394.1501, (CAuthors, 2021, College of Veterinary Medicine, University of Mosul.

This is an open access article under the CC BY 4.0 license (http://creativecommons.org/licenses/by/4.0/).

\section{Introduction}

Ethiopia has the largest population of equines in Africa and the second in the world next to China, by possessing 2.16 million horses, 8.44 million donkeys and 0.41 million mules (1). The country possesses approximately half of Africa's equine population with $37 \%$ donkeys, $58 \%$ horses and $46 \%$ mules; from these donkey's population of the Amhara region contributes $36.1 \%$ of the donkey's population of the country (2). In Ethiopiaone of the major health problems of donkey is colic, which commonly affects the health and welfare of donkeys. Research has demonstrated that the causes are complex and there are conflicting views about the impact of individual risk factors. Some risk factors were well documented, like change in feed, poor deworming practice, heavy work and Strongylus infestations $(3,4)$. Distension, enteritis, simple and complete obstruction are major causes of colic in equine, but lesion involving gastrointestinal tract (GIT) is the most important cause of colic (5). Clinical signs of impactive and spasmodic colic were varied with severity of pain. The most common clinical signs include pawing, lying down, rolling, sweating, stretching out, straining to 
defecate, abdominal distension, loss of appetite, dullness, and decreased or increased the number of bowel movements (6). The heart and respiratory rate may also become elevated; the mucous membranes may become white, purple blue or red (7). Diagnosis of impactive and spasmodic colic is based on history, physical and laboratory examination. Impactive colic was diagnosed by its clinical sings like over distention of abdomen, rolling, lying down, dullness, anorexia, decreased intestinal motility and distended colon, caecum and pelvic flexure with dry feces, while spasmodic colic is diagnosed by fecal examination and physical observation of clinical signs like frequent rolling, an audible gut sound heard from the distance and increase intestinal motility (4).

The key principles in the treatment of equines colic are pain management, decompression of the gastrointestinal tract, correcting biochemical and fluid imbalances, stimulation and maintenance of gastrointestinal motility and reduction of GIT inflammation (8). In Ethiopia, the prevalence of colic in donkey is not known, but one study was conducted in and around Bishoftu town reported a prevalence of $9.1 \%$. Among the colic types, impactive colic was high in donkeys, which accounts for $78.6 \%$ in Bishoftu town (4).

Even though, there is a study conducted in Bishoftu of Ethiopia about colic but, the study has limitations because it is not including hematological, electrolyte and/or biochemical alteration associated with the cases of colic. Besides, field veterinarians and clinicians also use ivermectin for the treatment of spasmodic colic in equine due to parasitic infections orally out of the manufacturer's instruction.

Therefore, this study was carried out with the objectives of comparing the therapeutic efficacy of different drug regimens in the treatment of impactive and spasmodic colic in donkeys and evaluating the physiological, hematological, electrolyte and biochemical changes in cases of colic.

\section{Materials and methods}

\section{Description of the study area}

The study was conducted at the University of Gondar veterinary clinic in Gondar town is located $740 \mathrm{~km}$ from Addis Ababa, the capital city of Ethiopia. It is located at the latitude of $12^{\circ} 36^{\prime}$ North and longitude of $27^{\circ} 2^{\prime}$ East with an altitude of 1800-2500 meters above sea level. The annual temperature of the area is $12.3-30^{\circ} \mathrm{C}$ with an average temperature of $19.7^{\circ} \mathrm{C}$. The livestock population of Central Gondar zone was estimated to be1, 556,549 cattle, 438,879 sheep, 599,289 goats, 8,789 horses, 3,351 mules, 227,871 donkeys, 2,032,905 poultry and 102,564 beehives (9).

\section{Study animals}

The study animals were twenty-five colic and non-colic donkeys that are presented to clinics.

\section{Study design}

A therapeutic clinical trial was conducted, to compare the efficacy of different drug regimens on donkeys suffering from spasmodic and impactive colic.

\section{Sampling method and sample size}

Donkeys showing suspected clinical signs of colic based on physical and systemic diagnostic techniques were selected purposively. A total of 25 donkeys were included in this study, from these 20 (11 females and males) colicky and 5 healthy donkeys age of 4-20 years and have a body weight of $100-225 \mathrm{~kg}$ were used.

\section{Data collection methods}

History of study donkeys like feed intake and type of feed, change in feed, treatment, types of work, defecation status, and flank distention were recorded beside that, clinical and physical examinations (gait and posture, mucus membrane color and CRT) of donkey and all donkeys with the history of dietary change and/or showing suspected clinical signs of colic were further assessed for deep physical and laboratory examinations. Complete auscultation of thorax and abdomen were performed to detect any abnormality in the heart, lung and intestine by using stethoscope. Also, rectal palpation and naso-gastric intubation were performed to detect the cause of colic. The hydration statuses of donkeys were assessed through skin tenting test and CRT before and after treatment.

\section{Laboratory examination}

Fecal, hematological, electrolyte and biochemical laboratory examinations were performed before and after treatment. For fecal examination, the fecal sample was taken from the rectum using arm length glove to detect gastrointestinal nematodes egg by direct fecal smear and floatation techniques. Fecal samples were collected from 10 donkeys with spasmodic colic at 0 (before treatment), 3, 7, 14 and 21 days' post-treatment. Then, anthelmintic efficacy was estimated using a fecal egg count reduction test (FECR) for helminths burden. McMaster techniques were used to count the egg per gram (EPG) of feces to estimate the parasitic loads, which was done in the University of Gondar parasitology laboratory. The arithmetic mean of the egg count and helminthes burden was calculated to determine the mean percentage reduction within each sub-group, according to the following formula FECR\%= (pre treatment - post treatment)/pre treatment*100 (10). The blood samples were collected before and after 48 hours of treatment for hematological, electrolyte and biochemical examinations. A total of $14 \mathrm{ml}$ of blood were collected from each colicky and control donkeys aseptically from jugular vein puncture by using plain and EDTA coated vacutainer tube. Then haematological values were immediately analysed by using automatic haematology analyzer (Automatic Full Digital cell counter, Beckman, USA). Total Leukocyte Count (TLC), 
Total Erythrocytes Count (TEC), Hemoglobin estimation (Hgb\%), Mean Cell Volume (MCV), Mean Cell Hemoglobin $(\mathrm{MCH})$, Mean Cell Hemoglobin Concentration (MCHC) and packed cell volume (PCV) were analyzed in the University of Gondar Specialized Teaching Hospital Hematology laboratory.

For biochemical and electrolyte analysis, the blood collected in plain vacutainer was allowed to clot at room temperature so separate serum. The serum sample was subjected to a standard biochemical analysis by using Spectrophotometer (Cecil 2031, Cambridge, England) to determine serum concentration of Aspartate aminotransferase (AST), Alkaline phosphatase (ALP), triglycerides (TG), glucose and total protein content. Serum concentrations of sodium $\left(\mathrm{Na}^{+}\right)$, potassium $\left(\mathrm{K}^{+}\right)$, calcium $\left(\mathrm{Ca}^{+}\right)$and Chloride $\left(\mathrm{Cl}^{-}\right)$were measured by Auto Electrolyte Analyser (Roch 986 UVL, Japan) at the University of Gondar Specialized Teaching Hospital (Table 1).

Table 1: Animal grouping and drug regimens

\begin{tabular}{|c|c|c|c|c|}
\hline Grouping & Sub group & No. & Type of drugs & Dosage, route frequency \\
\hline \multirow{5}{*}{ Spasmodic } & & & Ivermectin & $0.2 \mathrm{mg} / \mathrm{kg}, \mathrm{SC}$, stat \\
\hline & 1 & 5 & Hyoscine butyl bromide & $0.3 \mathrm{mg} / \mathrm{kg}$, IM, Stat \\
\hline & & & Fenbendazole & $10 \mathrm{mg} / \mathrm{kg}, \mathrm{PO}$, stat \\
\hline & II & 5 & Hyoscine butyl bromide & $0.3 \mathrm{mg} / \mathrm{kg}$, IM, Stat \\
\hline & & & Meloxicam & $0.6 \mathrm{mg} / \mathrm{kg}$,IM, stat \\
\hline \multirow{5}{*}{ Impactive } & I & 5 & liquid paraffin & $10 \mathrm{ml} / \mathrm{kg}$, nasogastric tube \\
\hline & & & Ringers lactate & $10 \mathrm{ml} / \mathrm{kg}$, IV, stat \\
\hline & & & Hyoscine butyl bromide & $0.3 \mathrm{mg} / \mathrm{kg}$, IM, stat \\
\hline & II & 5 & liquid paraffin & $10 \mathrm{ml} / \mathrm{kg}$, nasogastric tube \\
\hline & & & Ringers lactate & $10 \mathrm{ml} / \mathrm{kg}$, IV, stat \\
\hline Non-colic & - & 5 & Not medicated & --- \\
\hline
\end{tabular}

No.= number of donkeys, IV= intravenous, IM= intramuscular, $\mathrm{PO}=$ per oral. The effectiveness of the drugs was compared based on of time of clinical signs disappearance after treatment, change in physiological parameters, FECR\%, electrolyte, biochemical and hematological values change after treatment.

\section{Statistical analyses}

All data collected during the study period has been checked, coded and entered into Microsoft Excel and analyzed by using STATA software Version 14 and presented in forms of descriptive statistics. The before and after treatment data and between treatment groups were analyzed using t-test and $\mathrm{P}<0.05$ was considered as statistically significant.

\section{Results}

All physiological parameters were increased in all colic cases as compared to mean of control group donkeys but, the mean rectal temperature of donkeys with spasmodic and impactive colic were lower than the mean of the control group (Table 2).

In the present study, the mean of hematological values was recorded in both treatment and control groups before treatment (Table 3). There was no difference in mean of TEC and $\mathrm{MCH}$ between colic cases and control group. The mean of TLC and PCV were increased in colic cases as compared to mean of control group, whereas mean of $\mathrm{MCV}, \mathrm{MCHC}$ and $\mathrm{Hgb}$ decreased in colic cases as compared to mean of control group before treatment.

There were no mean differences in serum concentration of AST, ALP, TG, $\mathrm{Na}^{+}$and $\mathrm{Cl}^{-}$between colicky donkeys and control group (Table 4). The mean of total protein was increased, but there were decreased in mean serum concentration of glucose, calcium and potassium in colicky donkeys as compared to the control group before treatment.

The mean of fecal egg count reduction percentage and the range of Egg Per Gram (EPG) of feces for spasmodic colic donkey from day zero to day 21.

The mean fecal egg count reduction percentage of subgroup I and sub-group II were $97.30 \%$ and $79.85 \%$ with $95 \%$ lower confidence limit of $90.04 \%$ and $55.23 \%$ were found in current study, respectively (Table 5).

Meloxicam has better efficacy than hyoscine butyl bromide in the treatment of impactive colic donkeys since Most of the clinical signs of colic were treated by meloxicam (subgroup I) were disappear within 24 hours of time, whereas colicky donkeys treated with hyoscine butyl bromide (subgroup II) most of the clinical sings were disappear within 48 hours of time (Table 6).

There was statistically significant mean difference in heart rate, capillary refill time and rectal temperature in impactive colic between sub-groups after treatment, but there was no statistically significant difference in mean pulse and respiratory rate were found in the current finding (Table 7).

The mean difference of total leukocytes counts and PCV values between subgroups were statistically significant, but total erythrocytes, MCV, $\mathrm{MCH}, \mathrm{MCHC}$, and $\mathrm{Hb}$ values were not statistically between subgroups. The mean differences of 
serum concentration of glucose, $\mathrm{Ca}+$ and $\mathrm{K}+$ values of Subgroup I and Sub-group II were statistically significant, but there were no statistically significant mean differences of other biochemical and electrolyte values (Table 8).

Table 2: The mean of physiological parameters of treatment as compared to control group

\begin{tabular}{lcccccc}
\hline \multirow{2}{*}{ Parameters } & \multicolumn{3}{c}{ Colicky donkeys } & \multicolumn{3}{c}{ Control donkeys } \\
\cline { 2 - 7 } & $\mathrm{M} \pm \mathrm{SD}$ & Minimum & Maximum & $\mathrm{M} \pm \mathrm{SD}$ & Minimum & Maximum \\
\hline Heart rate & $62 \pm 13.46$ & 44 & 80 & $52 \pm 6.32$ & 44 & 60 \\
Pulse rate & $58.1 \pm 13.52$ & 40 & 77 & $48 \pm 6.32$ & 40 & 56 \\
Respiratory rate & $24.9 \pm 7.41$ & 12 & 40 & $18.4 \pm 4.56$ & 12 & 24 \\
CRT & $2.08 \pm 0.61$ & 1.5 & 3 & $1.7 \pm 0.27$ & 1.5 & 2 \\
Temperature & $36.34 \pm 0.87$ & 35 & 38 & $37.26 \pm 0.33$ & 36.9 & 37.7 \\
\hline
\end{tabular}

$* \mathrm{M} \pm \mathrm{SD}$ Values are mean \pm standard deviation.

Table 3: The mean of hematological values of treatment as compared to control group

\begin{tabular}{lcccccc}
\hline \multirow{2}{*}{ Parameters } & \multicolumn{3}{c}{ Colicky Donkeys } & \multicolumn{3}{c}{ Control Donkeys } \\
\cline { 2 - 7 } & M \pm SD & Minimum & Maximum & M \pm SD & Minimum & Maximum \\
\hline TEC $\left(* 10^{6} / \mathrm{uL}\right)$ & $5.85 \pm 0.9$ & 4.57 & 7.8 & $5.77 \pm 0.77$ & 4.96 & 6.77 \\
TLC $\left(* 10^{3} / \mathrm{uL}\right)$ & $15.29 \pm 3.31$ & 10.3 & 22.4 & $11.52 \pm 2.51$ & 9.3 & 18.2 \\
MCV (FL) & $57.31 \pm 5.74$ & 52.5 & 75.4 & $59.24 \pm 2.98$ & 55.5 & 62.8 \\
MCH (pg) & $20.86 \pm 1.51$ & 19 & 24.1 & $20.84 \pm 1.29$ & 19.5 & 22.7 \\
MCHC (g/dL) & $34.41 \pm 4.08$ & 29 & 43.2 & $34.74 \pm 1.08$ & 33.3 & 36.2 \\
PCV (\%) & $35.23 \pm 5.48$ & 28.9 & 48.3 & $34.12 \pm 3.34$ & 30.9 & 37.7 \\
Hgb (g/dL) & $10.92 \pm 1.92$ & 8.8 & 14 & $11.98 \pm 1.01$ & 10.9 & 13.2 \\
\hline
\end{tabular}

* $\mathrm{M} \pm \mathrm{SD}$ Values are mean \pm standard deviation.

Table 4: The mean of biochemical and electrolyte parameters of treatment as compared to control group

\begin{tabular}{lcccccc}
\hline \multirow{2}{*}{ Parameters } & \multicolumn{3}{c}{ Colicky Donkeys } & \multicolumn{3}{c}{ Control Donkeys } \\
\cline { 2 - 6 } & $\mathrm{M} \pm \mathrm{SD}$ & Minimum & Maximum & $\mathrm{M} \pm \mathrm{SD}$ & Minimum & Maximum \\
\hline $\mathrm{AST}(\mathrm{IU} / \mathrm{L})$ & $265.4 \pm 17.24$ & 235 & 290 & $265.3 \pm 16.86$ & 236 & 298 \\
$\mathrm{ALP}(\mathrm{IU} / \mathrm{L})$ & $329 \pm 46.06$ & 248 & 403 & $328.8 \pm 60.11$ & 249 & 403 \\
$\mathrm{TG}(\mathrm{mg} / \mathrm{dl})$ & $57.98 \pm 4.88$ & 51.98 & 67.4 & $58.26 \pm 4.20$ & 52.94 & 67 \\
$\mathrm{Glu}(\mathrm{mmol} / \mathrm{L})$ & $4.06 \pm 0.95$ & 2.8 & 5.2 & $4.27 \pm 0.75$ & 3.25 & 5.25 \\
$\mathrm{TP}(\mathrm{mmol} / \mathrm{L})$ & $6.19 \pm 1.08$ & 4.7 & 8 & $5.97 \pm 0.87$ & 4.85 & 7.11 \\
$\mathrm{Na}^{+}(\mathrm{mmol} / \mathrm{L})$ & $132.14 \pm 3.24$ & 127.5 & 138.5 & $132.28 \pm 3.92$ & 128.6 & 137.8 \\
$\mathrm{Ca}^{+}(\mathrm{mmol} / \mathrm{L})$ & $2.18 \pm 0.79$ & 1 & 3.7 & $2.86 \pm 0.27$ & 2.5 & 3.2 \\
$\mathrm{~K}^{+}(\mathrm{mmol} / \mathrm{L})$ & $2.92 \pm 1.48$ & 1.2 & 5.1 & $4.95 \pm 0.25$ & 4.65 & 5.3 \\
$\mathrm{Cl}(\mathrm{mmol} / \mathrm{L})$ & $99.55 \pm 2.11$ & 95.4 & 103 & $99.44 \pm 1.75$ & 97.5 & 101.5 \\
\hline
\end{tabular}

* $\mathrm{M} \pm \mathrm{SD}$ Values are mean \pm standard deviation.

Table 5: Arithmetic mean fecal egg counts $($ mean $\pm \mathrm{SD})$ and reduction percentage of spasmodic colic groups

\begin{tabular}{lcccccc}
\hline Days & \multicolumn{3}{c}{ Sub-group I } & \multicolumn{3}{c}{ Sub-group II } \\
\hline & Arithmetic mean & Range & Mean FECR \% & Arithmetic mean & Range & Mean FECR \% \\
3 & $1620 \pm 397.99$ & $800-3000$ & - & $1840 \pm 206.39$ & $1400-2600$ & - \\
7 & $780 \pm 101.98$ & $0-600$ & $90.42 \%$ & $920 \pm 48.98$ & $800-1100$ & $60.5 \%$ \\
14 & $20 \pm 20$ & $0-100$ & $98.76 \%$ & $600 \pm 44.72$ & $500-700$ & $77.39 \%$ \\
21 & 0 & 0 & $100 \%$ & $320 \pm 37.42$ & $200-400$ & $83.70 \%$ \\
M FECR\% & 0 & 0 & $100 \%$ & $40 \pm 24.49$ & $0-100$ & $97.82 \%$ \\
95\%LCL & - & - & $97.30 \%$ & - & - & $79.85 \%$. \\
95\% UCL & - & - & 90.04282 & - & - & 55.2319 \\
\hline
\end{tabular}

MFECR\%=Mean fecal egg count reduction percentage, 95\%LCL=95\% lower confidence limit, 95\%UCL=upper confidence limit. 
Iraqi Journal of Veterinary Sciences, Vol. 35, No. 4, 2021 (795-802)

Table 6: Time of clinical signs disappearance after treatment of impactive colicky donkeys

\begin{tabular}{|c|c|c|c|c|c|c|c|}
\hline \multirow{3}{*}{ Physical examination } & \multirow{3}{*}{ Clinical signs } & \multicolumn{6}{|c|}{ Time of clinical signs disappearance after treatment } \\
\hline & & \multicolumn{3}{|c|}{ Sub-group I (hours) } & \multicolumn{3}{|c|}{ Sub-group II (hours) } \\
\hline & & 1 & 24 & 48 & 1 & 24 & 48 \\
\hline \multirow[b]{2}{*}{ Abdomen } & Pain & $40 \%$ & $60 \%$ & & $20 \%$ & $60 \%$ & $20 \%$ \\
\hline & Distension & $20 \%$ & $80 \%$ & & 0 & $80 \%$ & $20 \%$ \\
\hline \multirow{4}{*}{$\begin{array}{l}\text { Abdominal } \\
\text { auscultation }\end{array}$} & Normal & $20 \%$ & $100 \%$ & & $60 \%$ & $80 \%$ & $20 \%$ \\
\hline & Decreased & $60 \%$ & $20 \%$ & & $20 \%$ & 0 & \\
\hline & Absent & 0 & 0 & & 0 & 0 & \\
\hline & Congested & $20 \%$ & $20 \%$ & & 0 & $20 \%$ & \\
\hline \multirow[t]{2}{*}{ Mucous membrane } & Pale & 0 & $20 \%$ & & 0 & 0 & $20 \%$ \\
\hline & Pink & $40 \%$ & $100 \%$ & & $60 \%$ & $80 \%$ & $100 \%$ \\
\hline \multirow{2}{*}{ Appetite } & Normal & 0 & $80 \%$ & $20 \%$ & 0 & $40 \%$ & $60 \%$ \\
\hline & In-appetence & $100 \%$ & $20 \%$ & 0 & $100 \%$ & $60 \%$ & \\
\hline \multirow{3}{*}{$\begin{array}{l}\text { Rectal sphincter } \\
\text { Behavior }\end{array}$} & Tight & $60 \%$ & $100 \%$ & & $40 \%$ & $80 \%$ & $20 \%$ \\
\hline & Dilated & 0 & $40 \%$ & & 0 & $40 \%$ & 0 \\
\hline & Dullness & $100 \%$ & $80 \%$ & $20 \%$ & $100 \%$ & $60 \%$ & $40 \%$ \\
\hline
\end{tabular}

Table 7: Mean difference of physiological parameters between sub-groups after treatment ( $12 \mathrm{hrs)}$

\begin{tabular}{|c|c|c|c|c|c|c|c|}
\hline \multirow{2}{*}{ Physiological parameters } & \multicolumn{2}{|c|}{ Mean after treatment } & \multirow{2}{*}{ Mean difference } & \multicolumn{2}{|c|}{ 95\% Interval difference } & \multirow{2}{*}{$\mathrm{T}$ value } & \multirow[b]{2}{*}{ Sig. } \\
\hline & Sub-group I & Sub-group II & & Lower & Upper & & \\
\hline Heart rate & 50.40 & 58.40 & -8 & -15.26300 & -.73700 & -2.54 & 0.035 \\
\hline Pulse rate & 48.40 & 54.40 & -6.4 & -14.95400 & 2.15400 & -1.725 & 0.123 \\
\hline Respiratory rate & 23.20 & 22.40 & 0.8 & -8.42402 & 10.0242 & 0.20 & 0.846 \\
\hline CRT & 1.52 & 1.64 & -0.12 & -.22313 & -.01687 & -2.683 & 0.023 \\
\hline Temperature & 37.4 & 36.6 & 0.8 & .00786 & 1.59214 & 2.329 & 0.048 \\
\hline
\end{tabular}

Table 8: Mean difference of hematological, electrolyte and biochemical values of impactive groups after 48 hours' treatment

\begin{tabular}{|c|c|c|c|c|c|c|c|}
\hline \multirow{2}{*}{ Hematological/ Biochemical } & \multicolumn{2}{|c|}{ Mean after treatment } & \multirow{2}{*}{ Mean difference } & \multicolumn{2}{|c|}{ 95\% Interval difference } & \multirow{2}{*}{$\mathrm{T}$ value } & \multirow{2}{*}{ Sig. } \\
\hline & Subgroup I & Subgroup II & & Lower & Upper & & \\
\hline TEC & 6.20 & 5.57 & 0.634 & -0.58336 & 1.85136 & 1.201 & 0.086 \\
\hline TLC & 11.42 & 13.34 & -1.92 & -3.99156 & 0.15156 & -2.137 & 0.046 \\
\hline MCV & 57.10 & 58.66 & -1.56 & -7.33358 & 4.21358 & -0.623 & 0.551 \\
\hline $\mathrm{MCH}$ & 21.08 & 22.16 & -1.08 & -3.01759 & 0.85759 & -1.285 & 0.235 \\
\hline MCHC & 37.14 & 37.98 & -0.84 & -6.47439 & 4.79439 & -0.344 & 0.740 \\
\hline $\mathrm{PCV}$ & 33.98 & 36.32 & -2.34 & -9.32297 & 4.64297 & -0.773 & 0.012 \\
\hline $\mathrm{Hgb}$ & 11.82 & 10.46 & 2.36 & -1.18498 & 3.90498 & 1.232 & 0.695 \\
\hline AST & 258.8 & 257.8 & 1.00 & -20.51886 & 22.51886 & 0.107 & 0.917 \\
\hline ALP & 305.6 & 305.8 & -0.20 & -81.30122 & 80.90122 & -1.088 & 0.308 \\
\hline TG & 56.94 & 58.72 & -1.78 & -12.60177 & 9.04177 & -0.379 & 0.714 \\
\hline GLU & 5 & 3.86 & 1.14 & 0.72364 & 1.55636 & 6.314 & 0.000 \\
\hline TP & 6 & 6.63 & -0.63 & -1.42330 & 0.15530 & -1.852 & 0.101 \\
\hline $\mathrm{Na}^{+}$ & 134.44 & 134.74 & -0.30 & -4.83304 & 4.23304 & -0.153 & 0.882 \\
\hline $\mathrm{Ca}^{+}$ & 3 & 2.02 & 0.98 & 0.39480 & 1.56520 & 3.862 & 0.005 \\
\hline $\mathrm{K}^{+}$ & 3.94 & 2.16 & 1.78 & 0.65927 & 2.90073 & 3.663 & 0.006 \\
\hline $\mathrm{Cl}^{-}$ & 98.82 & 100.38 & -1.56 & -4.09639 & 0.97639 & -1.418 & 0.194 \\
\hline
\end{tabular}

\section{Discussion}

In the current study, the mean physiological parameter values of heart rate, pulse rate, respiratory rate and capillary refill time were elevated in donkeys with spasmodic and impactive colic as compared to the control donkeys even with working donkeys of Ethiopia as previously reported by Lemma and Moges (11). This finding is in line with the 
previous study in Ethiopia $(12,4)$ and abroad (13). These physiological parameters elevations might be due to pain, violent struggle and over distension of abdomen, which had a direct effect on the cardiopulmonary system. The mean rectal temperature was decreased in colicky donkeys as compared to the control group, which is in agreement with the previous report in colicky donkeys (14). This might be due to loss of fluid and electrolyte from vascular space to the gastrointestinal lumen to hydrate the impacted ingesta and which in turn the resulting shock (15). The observed values of mean PCV and TLC were elevated in colicky donkeys as compared to control donkeys. The elevation in PCV value in the present finding is in agreement with report of Worku et al. (12) and Tadesse et al. (4); this due to dehydration and increasing concentration of circulating blood cells to compensate the fluid loss in donkeys with impactive colic (4). The elevation of TLC in the current finding is in line with the findings of Baher et al. (14), and might be due to stress in colicky donkeys, which results in liberation of corticosteroid to increased levels in the blood that prevent migration of white blood cells (majorly neutrophils) out of the blood vessels to the tissues (16). the mean serum concentrations of AST, ALP, TG, $\mathrm{Na}^{+}$and $\mathrm{Cl}^{-}$in colicky donkeys were close to control groups and this finding is similar to other studies done earlier on colicky donkeys and horses $(14,17)$. Other studies have reported hyperkalaemia, hypochloraemia and hyponatremia in colicky horses $(18,19)$, which disagree with the present findings. The mean serum calcium concentration was decreased in colicky donkeys as compared to the control donkeys. This result is in line with other studies in colicky donkeys and horses $(14,17,19)$.

The reason for decreased serum concentration of calcium in colic cases might be due to functional disturbances of the small intestine, which reduces the absorption of calcium (20). The mean serum concentration of potassium was decreased in the colicky donkeys as compared to control donkeys in the current findings. This result is in agreement with the findings of other previous studies in the colicky horse (21-23).

This might be a colicky donkey's altered feed intake and absorption and loss potassium through sweating and saliva. The elevation of the mean total plasma protein in colicky donkeys as compared to the control group in the present finding is in line with the previous report by Baher et al. (14). This could be due to dehydration developed during impactive colic as a result of fluid loss.

In the current study, subcutaneous administrations of ivermectin to donkeys were shown $97.30 \%$ mean fecal egg count reduction percentage with $95 \%$ lower confidence limit of $90.04 \%$.

This indicates that, parasites were susceptible for ivermectin and similar studies were also reported by (24-26). Donkeys treated with fenbendazole were shown $79.85 \%$ mean fecal egg count reduction percentage with $95 \%$ lower confidence limit of $55.23 \%$. This finding is in agreement with the previous report of Seyoum et al. (23) in horses. The Strongylus nematodes develop resistance tofenbendazolein donkeys observed in the current study. This might be due to improper deworming practice of fenbendazole by owners and the first-pass effect drug as described by Gokbulut et al. (24).

On the other hand, administration of meloxicam showed better efficacy than hyoscine butyl bromide in the treatment of impactive colic. Donkeys with impactive colic were treated with meloxicam become active and relieved from dullness, abdominal pain (rolling) and distension within 24 hours of time after treatment. This finding is in agreement with reports of Regan et al. (25) in UK.

The reduction in clinical parameters might be due to selective inhibition of cyclooxgenase 2 (COX2) by meloxicam, which was responsible for pathophysiological conditions beside that meloxicam has better gastrointestinal tolerability than other nonselective NSAIDs (26). Hyoscine butyl bromide was less effective in the treatment of impactive colic in donkeys as compared to meloxicam in the current study, which is in accordance with previous study on colic in horses (27).

In the present findings, there were statistically significant mean differences of the total leukocytes count, PCV, serum concentrations of glucose, calcium and potassium values between meloxicam treated and hyoscine butyl bromide treated groups. There is no other report to compare with the present findings. Hyoscine butyl bromide has a temporary inhibitory effect on intestinal motility, which might be undesirable in the treatment of impaction cases (15).

The mean of total leukocytes count was close to the control group in meloxicam treated group. These reductions of TLC in meloxicam treated group were due to selective inhibition of Cox 2 and subsequent subsiding of inflammations (28).

Moreover, as inflammation subsiding, blood circulation, intestinal motility and absorption returned normal subsequently. The mean serum concentrations of glucose become normal since the pain was relieved and the appetite of donkeys improved after treatment with meloxicam. The mean serum concentration of calcium and potassium were increased significantly after treatment of donkeys with meloxicam. This might be due to disappearances of clinical signs and the improvement of appetite, intestinal motility and absorption in donkeys (29) which results no extra loss of calcium and potassium after treatment of donkeys with meloxicam.

\section{Conclusion}

In general, intramuscular administration of meloxicam and subcutaneous administration of ivermectin was effective for the treatment of impactive and spasmodic colic in donkeys, respectively. Thus, meloxicam should be used by field veterinarians and clinicians since it is the most effective 
treatment of impactive colic in donkeys and subcutaneous administration of ivermectin should be practiced in the treatment of gastrointestinal nematodes in donkeys.

\section{Conflict of interest}

The authors of this article declared that there is no potential conflict of interest in the publication of this article

\section{Acknowledgments}

We would like to express our appreciation to Simada Woreda (Amhara regional state, Ethiopia) for funding the project.

\section{References}

1. Zeleke B. Status and growth trend of draught animal population in Ethiopia. J Dairy Vet Anim Res. 2017;6:2-3. [available at]

2. CSA. Agricultural sample Survey 2010-2011. Report on livestock and livestock characteristics. Ethiopia: Statistical Bull; 2011. 505 p.

3. Cox R, Burden F, GoSDen L, Praudman C, Trawfored A. Case control study to investigate risk factors for impaction colic in donkey in the UK. Prev Vet Med. 2009;92:179-187. DOI: 10.1186/1746-6148-3-1

4. Tadesse B, Abera B. Study on major causes of equine colic at the donkey sanctuary and SPANA clinic in Bishoftu town. J Vet Sci Technol. 2018;9:1-9. DOI: 10.4172/2157-7579.1000504

5. Robertson SA, Sanchez LC. Treatment of visceral pain in horses. Vet Clin North America. 2010;26:603-617. DOI: 10.1016/j.cveq..08.002

6. James NM. Overview of colic in horses. Kenilworth: Merck Inc; 2018. 28:75-75 p

7. Varga J. Equine emergency care. OSU Ext. 2009;330:262-7921. [available at]

8. David E. How to manage severe colic in the field? Am Asso Equine Practioners. 2011;18-21. [available at]

9. Central Gondar Zone Animal Resource and Development Office. Annual report. Athiopia: CGZARD; 2018. 1-10 p.

10. Coles G, Bauer C, Borgsteede FHM, Geerts S, Klei TR, Taylor MA, Waller PJ. World association for the advancement of veterinary parasitology methods for the detection of anthelmintic resistance in nematodes of veterinary importance. Vet Parasitol. 1992;44:35-44. DOI: $10.1016 / 0304-4017(92) 90141-\mathrm{U}$

11. Lemma A, Moges M. Clinical, hematological and serum biochemical reference values of working donkeys (Equusasinus) owned by transport operators in Addis Ababa, Ethiopia. Livest Res Rural Dev.2009;21:17. [available at]

12. Worku Y, Wondimagegn W, Aklilu N, Assefa Z, Gizachew A. Equine colic: Clinical epidemiology and associated risk factors in and around Debre Zeit. Trop Anim Helth Prod. 2017;49:959-965. DOI: 10.1007/s11250-017-1283-y

13. Sutton GA, Ertzman GR, Steiman A, Milgram J. Initial investigation of mortality rates and prognostic indicators in horses with colic in Israel: A retrospective study. Equine Vet J. 2009;41:482-486. DOI: $\underline{10.2746 / 042516409 \times 391060}$
14. Baher AA, Seri HI, Siham ES. Clinical, hematological and biochemical studies of colic in draught horses and donkeys in Nyala, Sudan. J Sci Technol. 2014;15:49-59. [available at]

15. Jennings KM, Laila C, Burford JH. Freeman SL. Prospective survey of veterinary practitioner's primary assessment of equine colic: Clinical features, diagnoses, and treatment of 120 cases of large colon impaction. BMC Vet Res. 2014;10:2-10. DOI: 10.1186/1746-6148-10S1-S2

16. Naylor JR, Taylor HA, Knowles JE, Wilford S, Linnenkohl W, Mair ST, Johns CI. Comparison of flunixinmeglumine and meloxicam for post-operative management of horses with strangulating small intestinal lesions. Equine Vet J. 2014;46:427-434. DOI: 10.1111/evj. 12224

17. Rani P, Singh SR, Singh S, Bansal KB. A study on clinico-biochemical evaluation in equine colic patients. J Anim Res. 2018;8:93-99. DOI: 10.30954/2277-940X.2018.00150.15

18. Sabev S, Dinev I. Myocardial infarction in a horse with colic, clinical, laboratory and pathomorphological findings. Bulg $\mathrm{J}$ Vet Med. 20112;15:287-293. [available at]

19. Hesselkilde EZ, Almind ME, Petersen J, Flethoj M, Praestegaard KF, Buhl R. Cardiac arrhythmias and electrolyte disturbances in colic horses. Acta Vet Scand. 2014;56:58-65. [available at]

20. Corley KTT. Therapeutics in practice: Treating electrolyte abnormalities in colic patients. Comp Cont Educ Pract. 2007;2:16-20. [available at]

21. Imam MS, Seri IH, Hassan T, Tigani AT, Zolain BH, Abakar DA. Therapeutic efficacy evaluation of anthelmintics activity of albendazole and ivermectin drench formulations in donkeys in Darfur, Sudan. Vet Arh. 2010;80:585-595. [available ta]

22. Fangama IM, Seri HI, Suliman ES, Imam AMS, Mozamel AE. Comparative efficacy evaluation of moxidectin and ivermectin injectable formulation against helminthes infestation of donkeys (Equus asinus) in Sudan. Vet Med J. 2013;59:1-8. [available ta]

23. Seyoum Z, Zewdu A, Dagnachew S, Bogale B. Anthelmintic resistance of Strongyle nematodes to ivermectin and fenbendazole on cart horses in Gondar, Northwest Ethiopia. Bio Med Res Int. 2017:1-6. DOI: 10.1155/2017/5163968

24. Gokbulut C, Akar F, Mckellar QA. Plasma disposition and fecal excretion of oxfendazole, fenbendazole and albendazole following oral administration to donkeys. Vet J. 2005;172:166-172. DOI: 10.1016/j.tvj1.2005.02.022

25. Regan HF, Hockenhull J, Pritchard CJ, Waterman EA, Whay RH. Identifying behavioral differences in working donkeys in response to analgesic administration. Equine Vet J. 2016;48:33. DOI: 10.1136/vetreco-2014-000105

26. Cook VL, Blikslager AT. The use of non-steroidal anti-inflammatory drugs in critically ill horses. J Vet Emerg Crit Care. 2015;25:76-88. DOI: $10.1111 /$ vec. 12271

27. Gitari A, Nguhiu J, Varma V, Mogoa E. Occurrence, treatment protocols, and outcomes of colic in horses within Nairobi County, Kenya. Vet World. 2017;10:1255-1263. DOI: 10.14202/vetworld.2017.1255-1263

28. Marshall JF, Blikslager AT. The effect of non-steroidal antiinflammatory drugs on the equine intestine. Equine Vet J. 2011;39:140144. DOI: $10.1111 / j .2042-3306.2011 .00398 . x$

29. Banse H, Cribb EA. Comparative efficacy of oral meloxicam and phenylbutazone in 2 experimental pain models in the horse. Can Vet J. 2017;58, 157-167. [available at] 


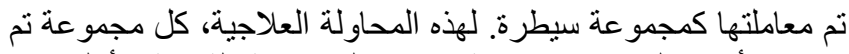

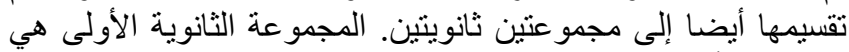

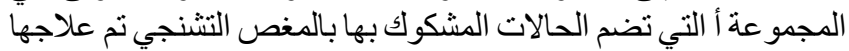

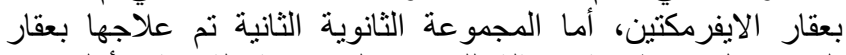

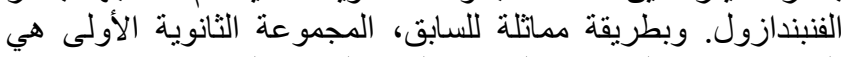

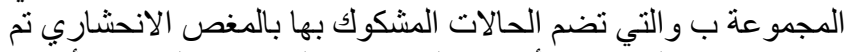

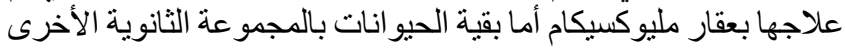

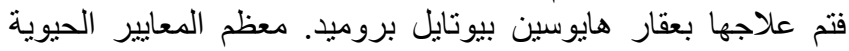

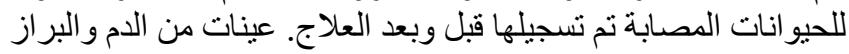

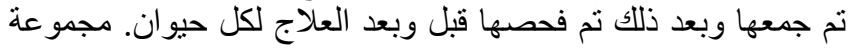

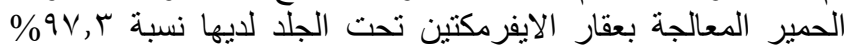

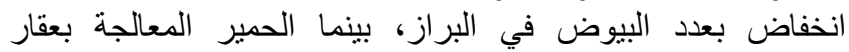

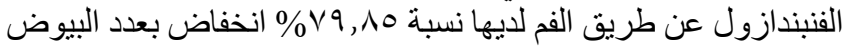

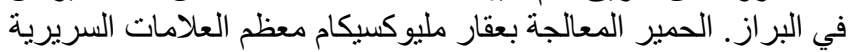

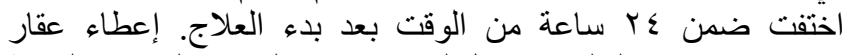

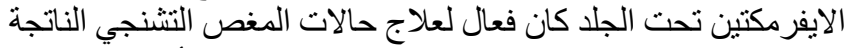

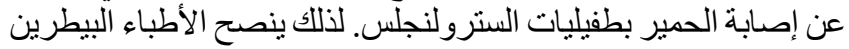

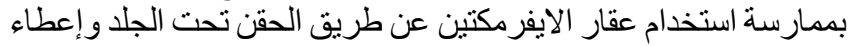

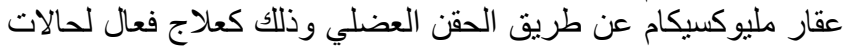
المغص التشنجي و الانحشاري في الحمير و على التو الي.

\section{المحاولات العلاجية لحالات المغص الانحشاري

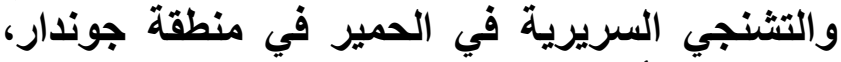 شمال غرب أثيوبيا}

\section{جي فنتاي كاسا، كينداي امينيو و برهانو ايلي}

'مدرسة الطب البيطري، جامعة ولاية سودا، 'مكتب الثروة الحيوانية

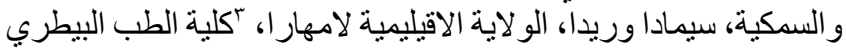

و وعلوم الحيوان، جامعة جوندار، جوندار، الثيوبيا لإيلاري

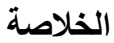

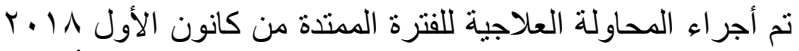

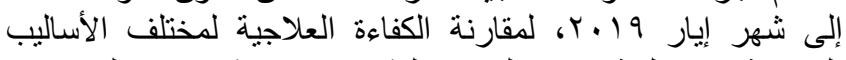

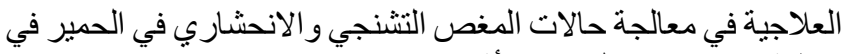

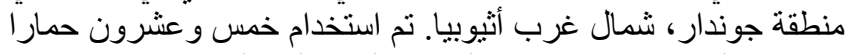

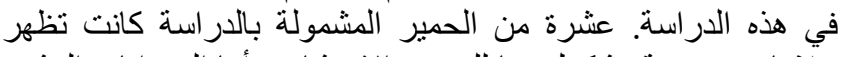

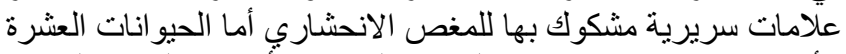

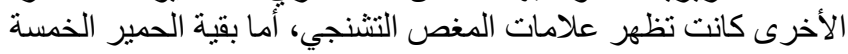

